\title{
Low-temperature heat capacities of synthetic pyrope, grossular, and pyrope ${ }_{60}$ grossular $_{40}$
}

\author{
H. T. HASELTON, JR* \\ Department of the Geophysical Sciences, University of Chicago, Chicago, IL 60637, U.S.A. \\ and \\ E. F. Westrum, JR \\ Department of Chemistry, University of Michigan, Ann Arbor, MI 48109, U.S.A.
}

(Received 6 June 1979; accepted in revised form 9 January 1980)

\begin{abstract}
The heat capacities of synthetic pyrope $\left(\mathrm{Mg}_{3} \mathrm{Al}_{2} \mathrm{Si}_{2} \mathrm{O}_{12}\right)$, grossular $\left(\mathrm{Ca}_{3} \mathrm{Al}_{2} \mathrm{Si}_{3} \mathrm{O}_{12}\right)$, and a solid solution pyrope ${ }_{60}$ grossular $_{40}\left(\mathrm{Mg}_{1.8} \mathrm{Ca}_{1.2} \mathrm{Al}_{2} \mathrm{Si}_{3} \mathrm{O}_{12}\right)$ have been measured by adiabatic calorimetry in the temperature range $10-350 \mathrm{~K}$. The samples were crystallized from glasses in a conventional pistoncylinder apparatus.

The molar thermophysical properties at $298.15 \mathrm{~K}\left(\mathrm{~J} \mathrm{~mol}^{-1} \mathrm{~K}^{-1}\right)$ are:
\end{abstract}

\begin{tabular}{lccc} 
& $\mathrm{C}_{\mathrm{p}}^{\circ}$ & $\mathbf{S}_{298}^{\circ}-\mathbf{S}_{\mathbf{0}}^{\circ}$ & $\mathbf{H}_{\mathbf{2 9 8}}^{\mathrm{o}}-\mathbf{H}_{\mathbf{0}}^{\mathrm{o}} / \mathbf{T}$ \\
\hline Pyrope & 325.31 & 266.27 & 47852 \\
Grossular & 333.17 & 260.12 & 47660 \\
Py $_{60} \mathrm{Gr}_{40}$ & 328.03 & 268.32 & 47990
\end{tabular}

The values for the end members are significantly greater than those presented previously for natural samples of pyrope and grossular. The pyrope ${ }_{60}$ grossular $_{40}$ exhibits an excess heat capacity below $120 \mathrm{~K}$; the maximum occurs at $45-50 \mathrm{~K}$. The anomalously high heat capacity of pyrope at low temperatures and the excess heat capacity of the solid solution are apparently caused by the unusually large, eight-fold coordination of $\mathrm{Mg}^{2+}$ in the garnet structure.

\section{INTRODUCTION}

GARNETS occur in a wide variety of geological environments and participate in reactions that can serve as pressure and temperature indicators, thus the thermodynamics of garnet solid solutions are of considerable petrologic interest. Thermophysical data for the pure end members are needed to evaluate the mixing relations in natural garnets. Unfortunately, with the exception of data on two natural samples, there are no measurements of low-temperature heat capacities for geologically important compositions. Kolesnik et al. (1977) report data for a pyrope-rich garnet

$$
\begin{aligned}
&\left(\mathrm{Mg}_{2.110} \mathrm{Fe}_{0.555}^{2+} \mathrm{Ca}_{0.306} \mathrm{Mn}_{0.010}\right)^{V I I I} \\
&\left(\mathrm{Al}_{1.953} \mathrm{Fe}_{0.043}^{3+} \mathrm{Cr}_{0.004}\right)^{V I} \mathrm{Si}_{3.020} \mathrm{O}_{12},
\end{aligned}
$$

but only the heat capacity at $298 \mathrm{~K}$ was adjusted to the end-member composition. WESTRUM et al. (1979) measured heat capacities from $5-600 \mathrm{~K}$ on a natural, gem-quality grossular of composition

$$
\begin{gathered}
\left(\mathrm{Ca}_{2.985} \mathrm{Fe}_{0.115}^{2+} \mathrm{Mn}_{0.041} \mathrm{Mg}_{0.013}\right)^{V I I I} \\
\left(\mathrm{Al}_{1.957} \mathrm{Ti}_{0.014} \mathrm{Mg}_{0.014}\right)^{V I} \\
\mathrm{Si}_{2.985} \mathrm{O}_{11.952}(\mathrm{OH})_{0.048} .
\end{gathered}
$$

* U.S. Geological Survey, 959 National Center, Reston, VA 22092, U.S.A.
In both of the above studies, compositional corrections were necessary for impurities whose thermodynamic properties had to be estimated.

Enthalpies of solution $\left(\Delta \mathrm{H}_{\text {soln }}\right)$ measured recently for synthetic garnets on the pyrope-grossular join by NEWTON et al. (1977a) at $970 \mathrm{~K}$ in a $2 \mathrm{PbO} \cdot \mathrm{B}_{2} \mathrm{O}_{3}$ melt show a positive deviation from ideality for the enthalpy of mixing $\left(\Delta \mathrm{H}_{\mathrm{mix}}\right)$, with a maximum of $\sim 9 \mathrm{~kJ} \mathrm{~mol}^{-1}$ displaced slightly toward pyrope-rich compositions. Heat capacities in the range $350-1000 \mathrm{~K}$ have been measured by differential scanning calorimetry for synthetic pyrope (NEWTON et al., 1977b), and synthetic and natural grossular (KRUPKA et al., 1979). Relative enthalpy measurements using a Tian-Calvet microcalorimeter have been reported over a similar temperature range for natural samples of pyrope and grossular (TOPOR et al., 1972; KiSELEVA et al., 1972).

Garnets of rocks in much of the lower crust and upper mantle are rich in pyrope and grossular components, thus the thermophysical properties of these end members are of particular importance. The apparent anomalously high entropy of pyrope (NEwTON et al., 1977a) and a postulated excess entropy of mixing for solid solutions on the pyrope-grossular join (HENSEN et al., 1975), inferred from phase equilibrium calculations, are additional reasons for the direct measurement of low-temperature heat capacities. 
Table 1. Cell edges of synthetic garnets. Uncertainties are least squares standard errors $(\mathrm{l} \sigma)$

\begin{tabular}{llll}
\hline Sample & $a_{0}(\mathrm{~nm})$ & Peaks & Tnt. Std. \\
\hline Pyrope & $1.14540(5)$ & 15 & silicon \\
Grossular & $1.18507(3)$ & 20 & spinel \\
Pyrope $_{60}$ grossular $_{40}$ & $1.1628(1)$ & 17 & spinel \\
\hline
\end{tabular}

Heat capacities for synthetic pyrope $\left(\mathrm{Mg}_{3} \mathrm{Al}_{2} \mathrm{Si}_{3} \mathrm{O}_{12}\right)$, grossular $\left(\mathrm{Ca}_{3} \mathrm{Al}_{2} \mathrm{Si}_{3} \mathrm{O}_{12}\right)$, and pyrope ${ }_{60}$ grossular $_{40}$ $\left(\mathrm{Mg}_{1.8} \mathrm{Ca}_{1.2} \mathrm{Al}_{2} \mathrm{Si}_{3} \mathrm{O}_{12}\right)$ have been measured to examine the possibility of excess heat capacity in solid solutions as well as to provide low-temperature thermophysical data on the end-members.

\section{SAMPLE PREPARATION}

\section{Pyrope}

An oxide mix was prepared from $\mathrm{MgO}$ (single crystal periclase, Muscle Shoals Electrochemical Corp.), $\mathrm{Al}(\mathrm{OH})_{3}$ (Fisher, reagent grade), and $\mathrm{SiO}_{2} \cdot n \mathrm{H}_{2} \mathrm{O}$ (Baker, reagent grade). All reagents were initially fired at $1675 \mathrm{~K}$ for $4-6 \mathrm{hr}$ and cooled in a desiccator containing Drierite immediately prior to weighing. All mixing, here and below, was done with a corundum mortar and pestle. The oxide mix was fused at $1875 \mathrm{~K}$ for $10 \mathrm{~min}$ in $325-350 \mathrm{mg}$ portions. The melt was quenched to a glass in a $\mathrm{Hg}$ bath and was subsequently homogenized by crushing and regrinding. again, with a corundum mortar and pestle. The glass was crystallized in graphite containers $(1623-1673 \mathrm{~K}, 30 \mathrm{kbar}, \mathrm{I} \mathrm{hr}$, $215 \mathrm{mg}$ per run) in a conventional piston-cylinder apparatus.

\section{Grossular}

The oxide mix was prepared from $\mathrm{CaCO}_{3}$ and $\mathrm{Al}_{2} \mathrm{O}_{3}$ (Baker, Ultrex grade) and $\mathrm{SiO}_{2}$ (acid-leached, natural quartz, Lisbon, Maryland). The $\mathrm{CaCO}_{3}$ was dried at $383 \mathrm{~K}$ for at least $48 \mathrm{hr}$. The firing of the oxides was the same as for the pyrope sample. The mix was decarbonated at $1023 \mathrm{~K}$ and fused at $1673 \mathrm{~K}$ for $1 \mathrm{hr}$. The glass was hom ogenized by crushing and regrinding and was crystallized $(1523 \mathrm{~K}, 25 \mathrm{kbar}, 3 \mathrm{hr}, 500-600 \mathrm{mg} / \mathrm{batch}$ in graphite containers).

\section{Pyrope $_{60}$ grossular $_{40}$}

The oxide mix was prepared from $\mathrm{CaCO}_{3}$ and $\mathrm{Al}_{2} \mathrm{O}_{3}$ (Baker, Ultrex grade), MgO (single crystal periclase, Muscle Shoals Electrochemical Corp.), and $\mathrm{SiO}_{2}$ (acidleached, natural quartz, Lisbon, Maryland. The drying procedure and decarbonation were the same as above. The mix was fused at $1773 \mathrm{~K}$ for $1.5 \mathrm{hr}$. Approximately one- third of the crushed and remixed glass was crystallized at $1573 \mathrm{~K}$ and $40 \mathrm{kbar}$ for $1 \mathrm{hr}$ in graphite containers. The balance was surrounded by a matrix of graphite and invar and was crystallized at 1623 and 46 kbar in Professor George C. Kennedy's laboratory at the University of California at Los Angeles. After the removal of the matrix. electron microprobe analyses of the garnet at the edges of several chips gave $\mathrm{FeO}$ concentrations of less than $0.03 \%$

Many of the early runs made on the pyrope ${ }_{60}$ grossular $_{40}$ were contaminated with aluminous clinopyroxene, apparently stabilized by the small amounts of $\mathrm{Na}_{2} \mathrm{O}$ in ordinary reagent grade chemicals. This problem was resolved by using high purity reagents and $20 \%$ seeding.

Graphite was removed from the samples by oxidation in air at $1023 \mathrm{~K}$. The graphite-invar matrix was removed by alternating treatments with $\mathrm{KNO}_{3}+\mathrm{H}_{2} \mathrm{SO}_{4}$ and $\mathrm{HNO}_{3}+\mathrm{HCl}$. No sign of gelatinization could be detected in garnet chips subjected to this treatment.

The crystallized garnet used for the heat capacity determinations was in the form of translucent discs $(6-8 \mathrm{~mm}$ dia) and chips composed of aggregated crystals $5-10 \mu \mathrm{m}$ in dimension. Microscopic examination showed very small amounts of an unidentified birefringent material in some of the chips, but when present the concentration was estimated to be much less than $1 \%$. All peaks in the X-ray diffraction scans were attributable to garnet.

The cell parameters, presented in Table 1 , were refined from powder diffraction data (BURNHAM, 1962). The data were obtained using $\mathrm{Cu} \mathrm{K}_{x}$ radiation at a scan rate of $1 / 8$ $2 \theta \mathrm{min}^{-1}$. U.S. National Bureau of Standards (NBS) silicon and spinel $\left[\mathrm{a}_{o}-0.80839(3) \mathrm{nm}\right.$, refined with NBS silicon] were used as internal standards. The positive deviation $[0.0015(1) \mathrm{nm}]$ of the pyrope ${ }_{60}$ grossular $_{40}$ unit cell edge from a linear combination of the end member values is in excellent agreement with that found by NEwTON et al. (1977a).

Chemical analyses of the garnets were obtained with the ARL electron microprobe equipped with a solid state detector at the University of Chicago. It is our experience (also R. C. Newton, personal communication, 1979) that good analyses of synthetic, fine-grained aggregates, such as the present materials, are difficult due to the problem of distinguishing grain boundaries with the electron microprobe optics. With this cautionary note, averaged analyses of at least 10 spots for each sample are listed in Table 2.

Table 2. Electron microprobe analyses of synthetic garnets

\begin{tabular}{|c|c|c|c|c|c|c|}
\hline \multicolumn{2}{|c|}{ Composition } & \multirow[t]{2}{*}{$\mathrm{CaO}$} & \multirow{2}{*}{$\begin{array}{c}\mathrm{MgO} \\
30.03\end{array}$} & \multirow{2}{*}{$\frac{\mathrm{Al}_{2} \mathrm{O}_{3}}{25.49}$} & \multirow{2}{*}{$\frac{\mathrm{SiO}_{2}}{45.06}$} & \multirow{2}{*}{$\frac{\text { Sum }}{\text { T(n).tol }}$} \\
\hline fyrops & Vrober & & & & & \\
\hline & Theoretical & & 30.00 & 25.29 & 44.71 & 700.00 \\
\hline \multirow[t]{2}{*}{ Grossular } & Probe & 36.79 & & 22.40 & 39.51 & 98.70 \\
\hline & Theoretical & 37.35 & & 22.64 & 40.01 & 100.00 \\
\hline \multirow[t]{2}{*}{$\because 600^{(r r} 40$} & Probe & 15.85 & 17.22 & 24.75 & 42.69 & 100.51 \\
\hline & Theoretical & 15.94 & 17.19 & 24.16 & 42.71 & 100.00 \\
\hline
\end{tabular}


The compositional range of the pyrope 60 grossular $_{40}$ was estimated to be $\pm 1-2 \mathrm{~mol} \%$ by visual examination of the shape and width of high-angle diffractions. The limited number of electron microprobe analyses are compatible with this conclusion.

The sample masses in vacuo were 9.7596, 10.1420, and $9.7926 \mathrm{~g}$ for pyrope, grossular, and pyrope 60 grossular $_{40}$, respectively. The formula weights used in the calculations were $403.127,450.452$, and $422.057 \mathrm{~g} \mathrm{~mol}^{-1}$ for pyrope, grossular, and pyrope 60 grossular 40 , respectively and are based on the 1975 values for the atomic weights (Commission on Atomic Weights. 1976).

\section{CALORIMETRY}

The same calorimeter (laboratory designation W-34) with a mass of $10.61 \mathrm{~g}$ was used for all heat capacity measurements. After loading and evacuation, a small measured amount of purified helium was added to promote thermal equlibration. The amounts of Apiezon-T grease, helium, and solder used for the measurements of the garnet samples closely match those used during the measurement of the heat capacity of the empty calorimeter, which was redetermined as a part of the present investigation. Corrections for differences in the masses of the above materials were small in comparison with the accuracy of the final results. When the end-member samples were measured, the fraction of the total heat capacity (calorimeter + sample) attributed to the samples increased from approximately 0.03 at $10 \mathrm{~K}$, to 0.3 at $100 \mathrm{~K}$, and to 0.5 at $350 \mathrm{~K}$. The values for the pyrope ${ }_{60}$ grossular $_{40}$ sample were similar except at $10 \mathrm{~K}$ where the fraction was 0.14 .

The heat capacity measurements were made in the Mark Il adiabatic cryostat described elsewhere (WESTRUM et al. 1968). A capsule-type platinum resistance thermometer (laboratory designation A-5) was used for temperature determinations. All determinations of mass, current, voltage, time, and temperature were referred to calibrations or standardizations performed by the U.S. National Bureau of Standards.

\section{RESULTS}

The experimental heat capacity values for pyrope, grossular, and pyrope ${ }_{60}$ grossular $_{40}$ are presented in Tables 3-5 in chronological sequence at the mean temperatures of the determinations. Temperature increments employed in the measurements can be inferred from the differences in the adjacent mean temperatures. The heat capacities have been adjusted for curvature to correct for the finite temperature increment of each measurement. The standard deviations of the heat capacities from polynomials, fitted by least squares, are $<5 \%$ below $50 \mathrm{~K},<1 \%$ from $50-100 \mathrm{~K}$, and $<0.1 \%$ above $100 \mathrm{~K}$ except for grossular for which the percentage is 0.15 above $100 \mathrm{~K}$. The data for pyrope prossular $_{40}$ are plotted in Fig. 1. For clarity only the fitted polynomials are shown for the end-member compositions. In addition, the smoothed values of KoLESNIK et al. (1977) for a natural pyrope sample are plotted below $50 \mathrm{~K}$ for comparison.

At the lowest temperatures the heat capacities were fitted to an equation of the form $C_{p}=\alpha \mathrm{T}^{3}$ to permit extrapolation of the measured data to zero Kelvin. This extrapolation accounts for less than $0.01 \%$ of the entropy function at $298.15 \mathrm{~K}$. The results for each
Table 3. Experimental heat capacities of pyrope, $\mathrm{Mg}_{3} \mathrm{Al}_{2} \mathrm{Si}_{3} \mathrm{O}_{12}$

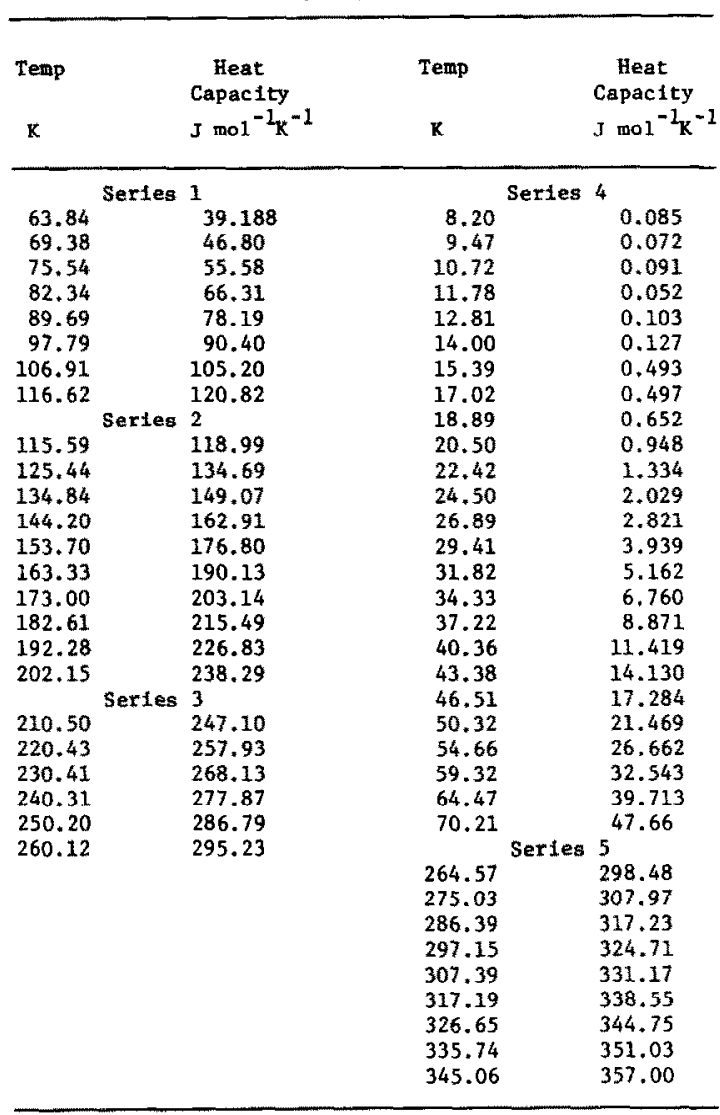

Table 4. Experimental heat capacities of grossular, $\mathrm{Ca}_{3} \mathrm{Al}_{2} \mathrm{Si}_{3} \mathrm{O}_{12}$

\begin{tabular}{|c|c|c|c|}
\hline Temp & $\begin{array}{l}\text { Heat } \\
\text { Capacity } \\
\mathrm{J} \text { mol }{ }^{-1} \mathrm{~K}^{-1}\end{array}$ & $\begin{array}{l}\text { Temp } \\
\mathrm{K}\end{array}$ & $\begin{array}{l}\text { Heat } \\
\text { Capacity } \\
J_{\text {mol }^{-1} \mathrm{~K}^{-1}}\end{array}$ \\
\hline \multicolumn{2}{|c|}{ Serfes 1} & \multicolumn{2}{|c|}{ Series 3} \\
\hline 129.79 & 137.06 & 11.45 & 0.074 \\
\hline 135.05 & 145.46 & 13.18 & 0.105 \\
\hline 144.12 & 159.91 & 14.92 & 0.333 \\
\hline 153.68 & 174.33 & 16.83 & 0.457 \\
\hline 162.33 & 187.38 & 18.89 & 0.607 \\
\hline 171.21 & 200.31 & 20.92 & 0.941 \\
\hline 180.34 & 212.63 & 22.87 & 1.223 \\
\hline 189.19 & 219.29 & 25.03 & 1.743 \\
\hline 198.00 & 235.69 & 27.47 & 2.316 \\
\hline 206.77 & 245,32 & 30.17 & 3.173 \\
\hline 215.87 & 255.66 & 33.34 & 4.556 \\
\hline 225.46 & 266.12 & 36.50 & 6.248 \\
\hline \multicolumn{2}{|c|}{ Series 2} & 39.43 & 7.939 \\
\hline 211.48 & 249.40 & 42.54 & 10.209 \\
\hline 217.70 & 253.83 & 45.70 & 12.676 \\
\hline 228.00 & 269.30 & 49.39 & 16.063 \\
\hline 239.30 & 280.40 & 53.78 & 20.166 \\
\hline 250.94 & 295.39 & \multicolumn{2}{|c|}{ Series 4} \\
\hline 262.35 & 299.14 & 56.55 & 23.905 \\
\hline 272.86 & 311.32 & 61.06 & 29.437 \\
\hline 282.43 & 321.73 & 66.45 & 36.479 \\
\hline 302.55 & 335.84 & 71.92 & 43.57 \\
\hline 312.73 & 344.52 & 78.09 & 52.62 \\
\hline 322.74 & 351.46 & 85.26 & 64.25 \\
\hline 332.62 & 358.39 & 92.98 & 76.41 \\
\hline 343.42 & 365.14 & 102.09 & 91.12 \\
\hline & & 111.75 & 107.02 \\
\hline & & 120.62 & 122.16 \\
\hline & & 129.78 & 137.08 \\
\hline & & 139.40 & 152.26 \\
\hline
\end{tabular}


Table 5. Experimental heat capacities of pyrope 60 grossular $40, \mathrm{Mg}_{1.8} \mathrm{Ca}_{1.2} \mathrm{Al}_{2} \mathrm{Si}_{3} \mathrm{O}_{12}$

\begin{tabular}{|c|c|c|c|c|}
\hline \multicolumn{2}{|l|}{ Temp } & \multirow{2}{*}{$\begin{array}{c}\text { Heat } \\
\text { Capacity } \\
\mathrm{Jmol}^{-1} \mathrm{~K}^{-1}\end{array}$} & \multirow{2}{*}{$\begin{array}{l}\text { Temp } \\
\mathrm{K}\end{array}$} & \multirow{2}{*}{$\begin{array}{c}\text { Heat } \\
\text { Capacity } \\
\mathrm{J} \mathrm{mol}^{-1} \mathrm{~K}^{-1}\end{array}$} \\
\hline K & & & & \\
\hline \multicolumn{3}{|c|}{ Series 1} & 284.45 & 318.26 \\
\hline 53.97 & & 27.063 & 294.61 & 325.09 \\
\hline 58.64 & & 32.505 & 304.64 & 332.79 \\
\hline 63.85 & & 38.979 & 314.18 & 339.47 \\
\hline 68.99 & & 45.80 & 323.81 & 346.26 \\
\hline 75.52 & & 54.84 & 333.99 & 353.05 \\
\hline 83.23 & & 66.77 & 344.31 & 360.80 \\
\hline 90.88 & & 78.76 & \multicolumn{2}{|c|}{ Series 4} \\
\hline 99.59 & & 91.87 & 7.89 & 0.018 \\
\hline 108.75 & & 106.50 & 9.65 & 0.247 \\
\hline 118.26 & & 121.62 & \multicolumn{2}{|c|}{ Series 5} \\
\hline 127.33 & & 136.32 & 5.68 & 0.027 \\
\hline 137.08 & & 151.30 & 6.50 & 0.030 \\
\hline 1.47 .54 & & 167.03 & 8.08 & 0.080 \\
\hline \multirow{2}{*}{\multicolumn{2}{|c|}{ Series }} & 2 & 9,60 & 0.193 \\
\hline & & 149.85 & 11.11 & 0.561 \\
\hline 146.21 & & 164.98 & 13.05 & 0.239 \\
\hline 156.40 & & 179.70 & 14.84 & 0.732 \\
\hline 166.37 & & 194.14 & 16.69 & 1.173 \\
\hline 176.18 & & 207.16 & 18.93 & 1.695 \\
\hline 185.89 & & 219.69 & 21.53 & 2.586 \\
\hline 195.56 & & 231.37 & 24.44 & 3.664 \\
\hline 205.34 & & 242,70 & 27.74 & 5.200 \\
\hline 215.06 & & 253.63 & 30.74 & 6.840 \\
\hline 224.79 & & 263.45 & 33.45 & 8.522 \\
\hline 234.66 & & 273.35 & 36.30 & 10.619 \\
\hline \multicolumn{2}{|c|}{ Series } & 3 & 39.19 & 12.756 \\
\hline 224.31 & & 262.95 & 42.34 & 15.319 \\
\hline 234.08 & & 273.01 & 45.96 & 18.548 \\
\hline 244.11 & & 283.85 & 49.50 & 22.026 \\
\hline 254.19 & & 291.77 & 53.96 & 26.858 \\
\hline 264.22 & & 300.84 & 59.21 & 32.877 \\
\hline 274.29 & & 309.43 & & \\
\hline
\end{tabular}

sample were again fitted to polynomials in temperature by a least-squares method. The derived thermodynamic functions are given in Tables 6-8. These values are considered to have a probable error of less than $0.1 \%$ above $100 \mathrm{~K}$.

\section{DISCUSSION}

Figure 2 is a deviation plot comparing the heat capacity measurements on natural and synthetic samples of pyrope and grossular. In calculating the deviations between the natural and synthetic pyrope, the heat capacity of the natural sample was based on the formula weight of pure pyrope $\left(403.127 \mathrm{~g} \mathrm{~mol}^{-1}\right)$. The natural grossular values were treated similarly by Westrum et al. (1979). Neither data set for the natural samples has been corrected for deviations from endmember composition. In both cases the values for the synthetic samples are significantly greater over most of the measured range than those of the uncorrected natural samples, although an adjustment to endmember composition would be expected to account for much of the discrepancies.

\section{Pyrope}

The heat capacity values measured on the natural pyrope garnet in the lowest temperature region require a comment. Figures 1 and 2 show that the heat capacity does not smoothly approach zero as $\mathrm{T} \rightarrow 0 \mathrm{~K}$. The $18.8 \mathrm{~mol}^{\circ} \%$ almandine content of the garnet may be partly responsible. Almandine is known to undergo paramagnetic to antiferromagnetic ordering at $7.5 \mathrm{~K}$ (Prandl, 1971) for which the theoretical entropy contibution is $3 R \ln (2 \mathrm{~S}+1)=40.14 \mathrm{~J} \mathrm{~mol}^{-1} \mathrm{~K}^{-1} \quad$ (KITTEL, 1976 ; UlbRICH and WALDBaUM, 1976). The apparent anomaly may represent the high-temperature tail of this transition. At higher temperatures, the adjustment to end-member composition will be dominated by the almandine contribution. Because the correction will be large and because various methods of estimating the almandine heat capacity vary widely in results, no attempt was made to correct the heat capacity of the natural pyrope sample for additional components. Much of the discrepancy may be removed, however, by such a correction. KOLESNIK et al. (1977) give a corrected value for $C_{p, 298}=320.24 \mathrm{~J} \mathrm{~mol}^{-1} \mathrm{~K}-1$ which is $1.5 \%$ low in comparison to our measurements on synthetic pyrope.

A value of $S_{298}^{\mathrm{o}}=268 \mathrm{~J} \mathrm{~mol}^{-1} \mathrm{~K}^{-1}$ based on the univariant reaction enstatite + spinel $=$ pyrope + forsterite was calculated by NEwTON et al. $(1977 \mathrm{~b})$. The absence of a heat capacity anomaly and the relatively good agreement between the observed $\mathrm{S}_{298}^{\circ}$ and the value calculated from phase equlibirum studies is strong evidence against $\mathrm{Mg}^{2+}$ positional disorder as proposed by ZEMANN and ZEMANN (1961) and KLEBER et al. (1969) from X-ray studies.

\section{Grossular}

In the natural grossular $\mathrm{FeO}$ and $\mathrm{H}_{2} \mathrm{O}$ are the major additional oxides attributed by WESTRUM et al. (1979) to almandine and hydrogrossular components, respectively. The $C_{p}$ values, adjusted to end-member composition at temperatures $>100 \mathrm{~K}$ by Westrum et al. (1979), are shown by solid triangles in Fig. 2. Unfortunately, the corrections increase the deviation with regard to the synthetic sample, KRUPKA et al. (1979), in a differential scanning calorimetry study on synthetic grossular and a natural grossular of similar composition to that used by Westrum et al. (1979), also observed lower heat capacities for the natural sample in the temperature range $350-700 \mathrm{~K}$. The synthetic grossular in their study was crystallized hydrothermally from a gel at $923 \mathrm{~K}$ and 517 bar, a synthesis procedure quite different from the one in the present work. They did not detect a significant difference in the heat capacities of their natural and synthetic samples in the higher temperature $(700-1000 \mathrm{~K})$ section of their study. At least part of the difference in behavior of the corrected natural grossular and the synthetic shown in Fig. 2. could relate to the heat capacity approximation for hydrogrossular used by WeSTRUM et al. (1979). It is probable from structural considerations that the use of brucite to model hydroxyls in a hydrogarnet, as was done by these authors, over-estimates their contribution to the heat capacity (A. B. THOMPSON, personal communication, 1979). A differential scanning calorimetry study might readily resolve this point. 
Table 6. Molar thermodynamic functions of pyrope, $\mathrm{Mg}_{3} \mathrm{Al}_{2} \mathrm{Si}_{3} \mathrm{O}_{12}$, formula weight $=403.127 \mathrm{~g} \mathrm{~mol}^{-1}$

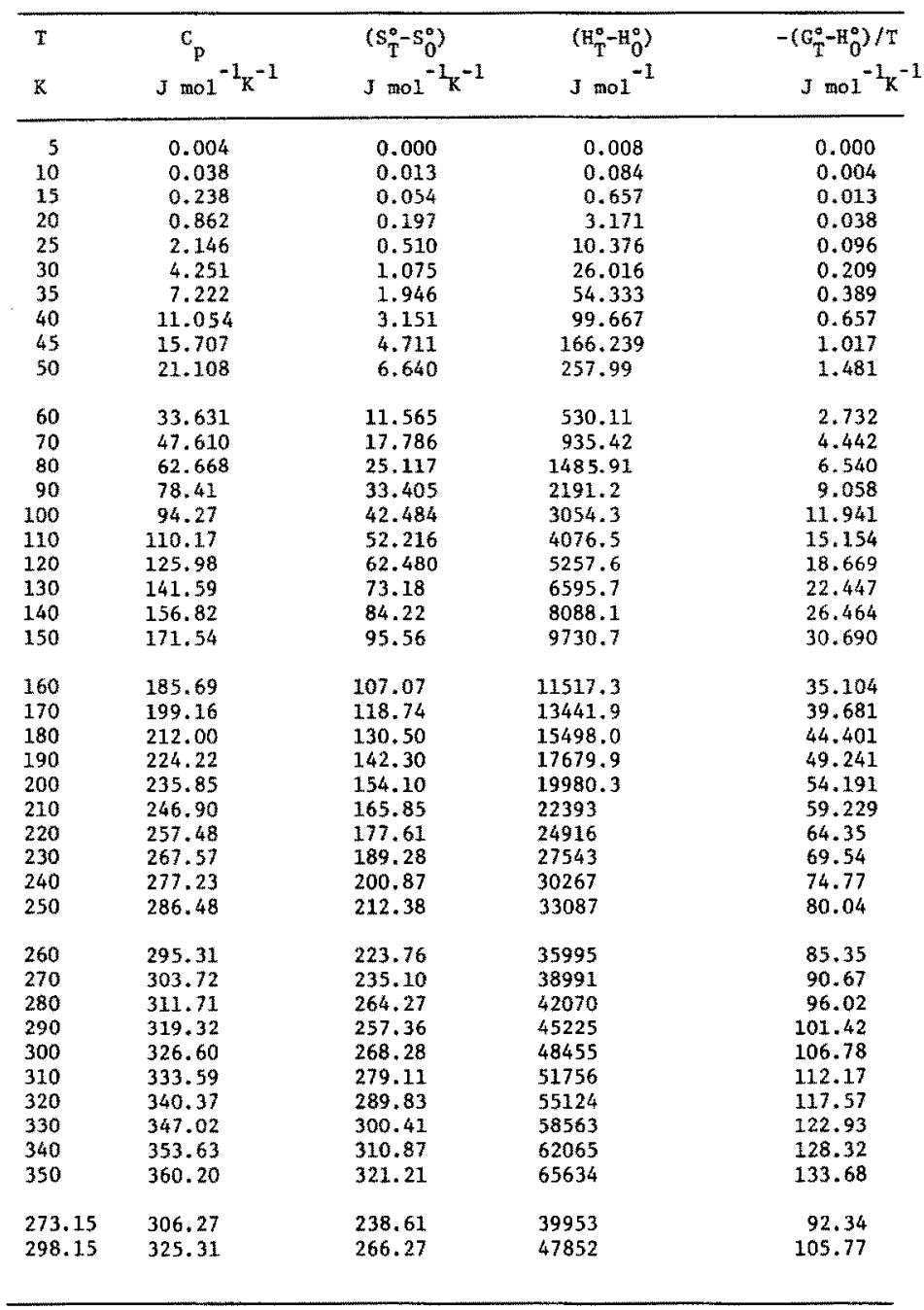


Table 7. Molar thermodynamic functions of grossular, $\mathrm{Ca}_{3} \mathrm{Al}_{2} \mathrm{Si}_{3} \mathrm{O}_{12}$, formula weight $=450.452 \mathrm{~g} \mathrm{~mol}^{-1}$

\begin{tabular}{|c|c|c|c|c|}
\hline $\mathrm{I}$ & $c_{p}$ & $\left(S_{T}^{0}-s_{0}^{0}\right)$ & $\left(H_{T}^{*}-H_{0}^{*}\right)$ & $-\left(G_{T}^{\circ}-H_{0}^{\circ}\right) / T$ \\
\hline $\mathrm{k}$ & $J \operatorname{moz}^{-1} K^{-1}$ & $J \mathrm{~mol}^{-1} \mathrm{~K}^{-1}$ & $J$ nto $1^{-1}$ & $J \operatorname{mol}^{-1} k^{-1}$ \\
\hline 5 & 0.013 & 0.004 & 0.017 & 0.000 \\
\hline 10 & 0.071 & 0.029 & 0.218 & 0.008 \\
\hline 15 & 0.293 & 0.092 & 1.021 & 0.025 \\
\hline 20 & 0.803 & 0.238 & 3.619 & 0.059 \\
\hline 25 & 1.715 & 0.506 & 9.719 & 0.117 \\
\hline 30 & 3.167 & 0.937 & 21.661 & 0.213 \\
\hline 35 & 5.322 & 1.577 & 42.568 & 0.360 \\
\hline 40 & 8.293 & 2.473 & 76.258 & 0.565 \\
\hline 45 & 12.100 & 3.661 & 126.897 & 0.841 \\
\hline 50 & 16.707 & 5.167 & 198.602 & 1.197 \\
\hline 60 & 27.886 & 9.167 & 419.61 & 2.171 \\
\hline 70 & 41.058 & 14.431 & 762.91 & 3.535 \\
\hline 80 & 55.789 & 20.861 & 1245.95 & 5.289 \\
\hline 90 & 71.630 & 28.338 & 1882.42 & 7.422 \\
\hline 100 & 87.738 & 36.719 & 2679.0 & 9.929 \\
\hline 110 & 104.27 & 45.852 & 3638.8 & 12.774 \\
\hline 120 & 120.88 & 55.639 & 4764.7 & 15.933 \\
\hline 130 & 137.32 & 65.98 & 6055.9 & 19.380 \\
\hline 140 & 153.43 & 76.74 & 7509.9 & 23.091 \\
\hline 150 & 168.99 & 87.86 & 9122.4 & 27.037 \\
\hline 160 & 183.97 & 99.24 & 10887.6 & 31.192 \\
\hline 170 & 198.24 & 110.83 & 12799.3 & 35.535 \\
\hline 180 & 211.84 & 122.55 & 14850.3 & 40.041 \\
\hline 190 & 224.76 & 134.35 & 17033.5 & 44.693 \\
\hline 200 & 237.07 & 146.19 & 19343.5 & 49.472 \\
\hline 210 & 248.82 & 158.03 & 21774 & 54.363 \\
\hline 220 & 260.04 & 169.87 & 24317 & 59.342 \\
\hline 230 & 270.83 & 181.67 & 26974 & 64.392 \\
\hline 240 & 281.17 & 193.43 & 29732 & 69.538 \\
\hline 250 & 291.08 & 205.10 & 32593 & 74.726 \\
\hline 260 & 300.58 & 216.69 & 35551 & 79.96 \\
\hline 270 & 309.70 & 228.24 & 38606 & 85.23 \\
\hline 280 & 318.40 & 239.66 & 41744 & 90.54 \\
\hline 290 & 326.73 & 250.96 & 44970 & 95.90 \\
\hline 300 & 334.64 & 262.17 & 48279 & 101.25 \\
\hline 310 & 342.17 & 273.26 & 51664 & 106.61 \\
\hline 320 & 349.41 & 284.26 & 55120 & 112.01 \\
\hline 330 & 356.39 & 295.10 & 58651 & 117.36 \\
\hline 340 & 363.34 & 305.85 & 62250 & 112.76 \\
\hline 350 & 370.33 & 316.48 & 65915 & 128.16 \\
\hline 273.15 & 312.50 & 231.84 & 39585 & 86.90 \\
\hline 298.15 & 333.17 & 260.12 & 47660 & 100.25 \\
\hline
\end{tabular}




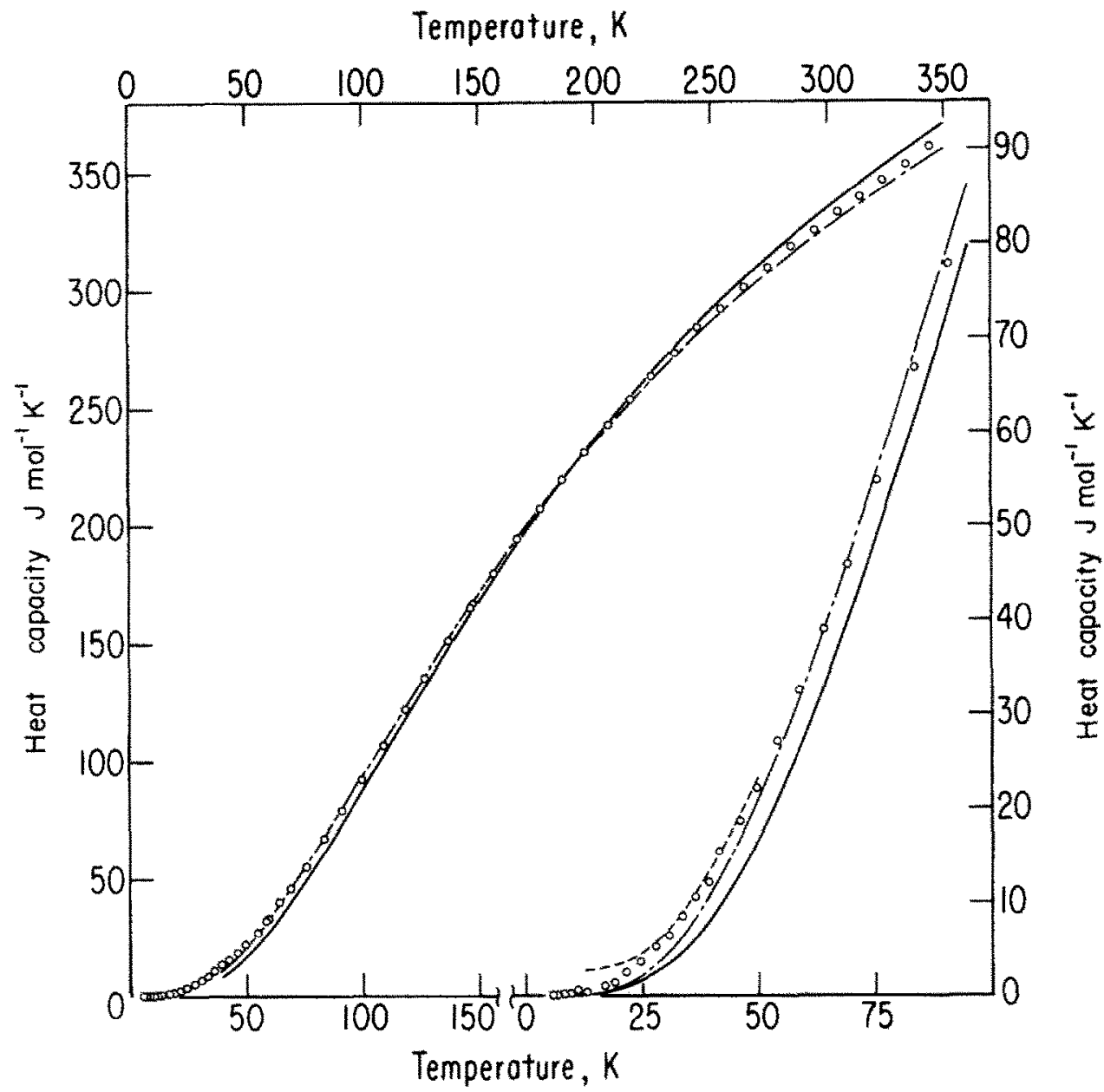

Fig. 1. Molar heat capacities of synthetic pyrope, grossular, and pyrope 60 grossular 40 . Circles are the data points for the mix crystal. Smoothed values are given for grossular - and pyrope- Smoothed values for natural pyrope, adjusted to the formula weight of pyrope, are given by a dashed line at $T<50 \mathrm{~K}$. The lower temperature region has been expanded at the right.

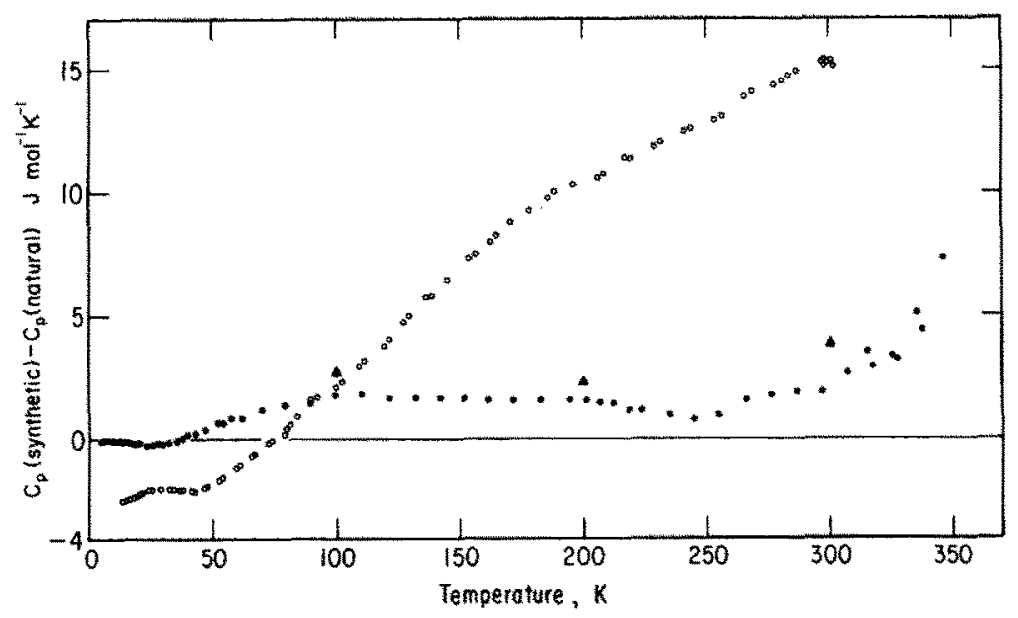

Fig. 2. Deviation plot. Differences between natural and synthetic samples of pyrope and grossular are given by

$$
\Delta C_{p}=C_{p} \text { (synthetic) }-C_{p} \text { (natural) }
$$

Open circles are for pyrope; solid circles are for grossular. Natural grossular values, adjusted to endmember composition, are indicated at three temperatures by solid triangles. 
Table 8. Molar thermodynamic functions of pyrope 6 grossular $_{40}$, $\mathrm{Mg}_{1.8} \mathrm{Ca}_{1.2} \mathrm{Al}_{2} \mathrm{Si}_{3} \mathrm{O}_{12}$, formula weight $=422.057 \mathrm{~g} \mathrm{~mol}^{-1}$

\begin{tabular}{|c|c|c|c|c|}
\hline $\mathrm{K}$ & $\begin{array}{c}c_{P} \\
J \text { mo1 } \\
-1 K^{-1}\end{array}$ & $\begin{array}{l}\left(S_{T^{0}}-S_{0}^{0}\right) \\
J \text { mol } 1^{-1} K^{-1}\end{array}$ & $\begin{array}{l}\left(\mathrm{H}_{\mathrm{T}}^{\circ}-\mathrm{H}_{0}^{\circ}\right) \\
3 \mathrm{~mol}^{-1}\end{array}$ & $\begin{array}{l}-\left(\mathrm{G}_{\mathrm{T}}^{0}-\mathrm{H}_{0}^{0}\right) / \mathrm{T} \\
\quad J \mathrm{~mol}^{-1} \mathrm{~K}^{-1}\end{array}$ \\
\hline 5 & .000 & .008 & .033 & .000 \\
\hline 10 & .188 & .050 & .385 & .013 \\
\hline 15 & .799 & .222 & 2.628 & .050 \\
\hline 20 & 2.017 & .602 & 9.389 & .134 \\
\hline 25 & 3.912 & 1.247 & 23.932 & .289 \\
\hline 30 & 6.460 & 2.176 & 49.597 & .523 \\
\hline 35 & 9.615 & 3.397 & 89.538 & .841 \\
\hline 40 & 13.355 & 4.920 & 146.725 & 1. 251 \\
\hline 45 & 17.686 & 6.740 & 224.10 & 1.757 \\
\hline 50 & 22.610 & 8.853 & 324.60 & 2.360 \\
\hline 60 & 34.054 & 13.958 & 606.35 & 3.849 \\
\hline 70 & 47.120 & 20.171 & 1011.02 & 5.728 \\
\hline 80 & 61.668 & 27.393 & 1553.65 & 7.975 \\
\hline 90 & 77.24 & 35.560 & 2248.5 & 10.577 \\
\hline 100 & 92.759 & 44.497 & 3098.3 & 13.514 \\
\hline 110 & 108.53 & 54.078 & 4104.5 & 16.765 \\
\hline 120 & 124.39 & 64.18 & 5268.9 & 20.292 \\
\hline 130 & 140.16 & 74.77 & 6591.9 & 24.075 \\
\hline 140 & 155.65 & 85.73 & 8071.4 & 28.083 \\
\hline 150 & 170.71 & 96.99 & 9703.5 & 32.300 \\
\hline 160 & 185.18 & 108.49 & 11483.4 & 36.702 \\
\hline 170 & 199.03 & 120.12 & 13405.1 & 41.267 \\
\hline 180 & 212.17 & 131.88 & 15461.6 & 45.974 \\
\hline 190 & 224.64 & 143.68 & 17646.0 & 50.802 \\
\hline 200 & 236.52 & 155.52 & 19952.2 & 55.743 \\
\hline 210 & 247.82 & 167.32 & 22376 & 60.777 \\
\hline 220 & 258.57 & $179 \times 08$ & 24907 & 55.90 \\
\hline 230 & 268.86 & 190.83 & 27543 & 71.04 \\
\hline 240 & 278.74 & 202.46 & 30284 & 76.27 \\
\hline 250 & 288.19 & 214.05 & 33116 & 81.59 \\
\hline 260 & 297.23 & 225.52 & 36045 & 86.90 \\
\hline 270 & 305.85 & 236.90 & 39062 & 92.22 \\
\hline 280 & 314.05 & 248.15 & 42162 & 97.61 \\
\hline 290 & 321.92 & 259.32 & 45342 & 102.97 \\
\hline 300 & 329.41 & 270,37 & 48597 & 108.37 \\
\hline 310 & 336.60 & 281.29 & 51928 & 113.76 \\
\hline 320 & 343.63 & 292.09 & 55329 & 119.20 \\
\hline 330 & 350.54 & 302,75 & 58798 & 124.60 \\
\hline 340 & 357.44 & 313.34 & 62342 & 130.00 \\
\hline 350 & 364.34 & 323.80 & 65948 & 135.35 \\
\hline 273,15 & 308.49 & 240.45 & 40028 & 93.93 \\
\hline 298.15 & 328.03 & 268.32 & 47990 & 107.36 \\
\hline
\end{tabular}

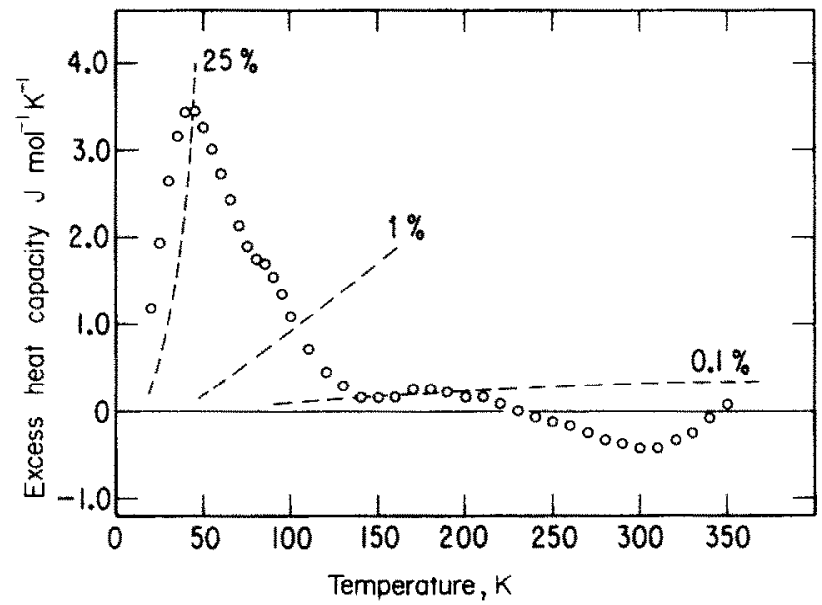

Fig. 3. Excess heat capacity of pyrope ${ }_{60}$ grossular $_{40}$ compared to a linear combination of the end member heat capacities. Pcrcentages are based on the lincar combination.

$$
\left.\left.\mathrm{C}_{\mathrm{p}} \text { (excess) }=\mathrm{C}_{\mathrm{p}} \text { ( } \text { pyrope }_{60} \text { grossular }_{40}\right)-\left[0.6 \mathrm{C}_{\mathrm{p}} \text { (pyrope }\right)+0.4 \mathrm{C}_{\mathrm{p}} \text { (grossular) }\right] \text {. }
$$


Pyrope $_{60}$ grossular $_{40}$

The excess heat capacity of the pyrope ${ }_{60}$ grossular $_{40}$ composition shown in Fig. 3 is based on a linear combination of the end-member heat capacities. Though the greatest excess heat capacity, $25 \%$ of the linear combination, occurs at $40-45 \mathrm{~K}$, the relative contribution is greater at lower temperatures. Above $115-120 \mathrm{~K}$ the excess heat capacity is within the experimental error. The accumulated $S_{298.15}^{x_{5}}-S_{0}$ is $4.5(3) \mathrm{J} \mathrm{mol}^{-1} \mathrm{~K}^{-1}$. This value can be compared to an excess of $13.0 \mathrm{~J} \mathrm{~mol}^{-1} \mathrm{~K}^{-1}$ estimated by HeNSEN et al. (1975) from phase equilibrium experiments which were limited to pyrope-rich compositions. By analogy with the excess entropy of mixing calculated by THOMPSON and Hovis (1979) in the analbite-sanidine series, the maximum excess may be displaced to grossular-rich compositions. Without additional information, however, any asymmetry cannot be assessed.

The excess heat capacity of the pyrope ${ }_{60}$ grossular $_{40}$ composition and the apparently high heat capacity of pyrope may be related to the coordination of magnesium in garnets. GibBS and SMrTH (1965) reported a larger than expected thermal ellipsoid for $\mathbf{M g}^{2+}$ which was attributed to its unusually large, eight-fold coordination. In the solid solution, the occupation of this structural position in part by calcium might expand it, increasing the vibrational amplitude of the magnesium ions and their contribution to the heat capacity. This trend can be observed in the lowtemperature in Fig. 1.

\section{Note added in proof}

Very recently KOLESNIK et al. (Geokhimiya, 1979 , 713-721) have published heat capacity data $(13-300 \mathrm{~K})$ for a natural grossular sample. At $298 \mathrm{~K}, \mathrm{C}_{f}=334.26 \mathrm{~J} \mathrm{~mol}^{-1}$ $\mathrm{K}^{-1}$ and $\mathrm{S}^{\circ}=259.78 \mathrm{~J} \mathrm{~mol}^{-1} \mathrm{~K}^{-1}$. The composition of the sample is very close to end-member grossular, and the thermophysical functions at $298 \mathrm{~K}$ agree within error with those of the synthetic grossular in the present study.

Acknowledgements-It is pleasure to acknowledge the advice and support of R. C. NEWTON. We are also indebted to J. BOERIO-GOATES and R. D. CHIRICo for their assistance with the calorimetry. We thank I. R. Golnsmith and T. J. B. HOLLAND for reading the manuscript and A. NAVROTSKY and G. L. Hovis for their constructive reviews. The project was supported by NSF grant EAR74-22851 (R. C. NEWTON ) and by the Structural Chemistry and Chemical Thermodynamics Program, Chemistry Section, National Science Foundation under contract GP-42525 (EFW). Additional support was provided by the Materials Research Laboratory Program of the National Science Foundation at the University of Chicago.

\section{REFERENCES}

Burnham C. W. (1962) Lattice constant refinement. Carnegie Inst. Washington Yearb. 61, 132-135.

Commission on atomic weights, I.U.P.A.C. (1976) Atomic weights of the elements 1975. Pure Appl. Chem. 47, 75-95

GibBs G. V. and SMITH J. W. (1965) Refinement of the crystal structure of synthetic pyrope. Am. Mineral. $\mathbf{5 0}$, 2023-2039.

Hensen B. J., Schimd R. and Wood B. J. (1975) Activitycomposition relations for pyrope-grossular garnet. Contrib. Mineral. Petrol. 51, 161-166.

Kiseleva I. A., Topor N. D. and Melchakova L. V. (1972) Experimental determination of heat content and heat capacity in grossular, andradite and pyrope. Geokhimiya 1372-1379.

KITTEL C. (1976) Introduction to Solid State Physics, 5th edn, 599 pp. Wiley.

Kleber W., Jost K. H. and Ziemer B. (1969) Zur Koordination des Magnesiums in Pyrop und Untersuchungen uber dessen thermische Zersetzung. Krist. Tech. 4, 423-429.

KolesniK Y. N., Nogteva V. V. and Paukov I. E. (1977) Heat capacity of pyrope within the temperature ranges of $13-300^{\circ} \mathrm{K}$. Thermodynamical properties of some natural garnets. Geokhimiya 533-541.

Krupka K. M., Robie R. A. and Hemingway B. S. (1979) High-temperature heat capacities of corundum, periclase, anorthite, $\mathrm{CaAl}_{2} \mathrm{Si}_{2} \mathrm{O}_{8}$ glass, muscovite, pyrophyllite, $\mathrm{KaISi}_{3} \mathrm{O}_{8}$ glass, grossular, and $\mathrm{NaAlSi}_{3} \mathrm{O}_{8}$ glass. Am. Mineral. 64, 86-101.

Newton R. C., Charlu T. V. and Kleppa O. J. (1977a) Thermochemistry of high pressure garnets and clinopyroxenes in the system $\mathrm{CaO}-\mathrm{MgO}-\mathrm{Al}_{2} \mathrm{O}_{3}-\mathrm{SiO}_{2}$, Geochim. Cosmochem. Acta 41, 369-377.

Newton R. C., Thompson A. B. and Krupka K. M (1977b) Heal capacity of synthetic $\mathrm{Mg}_{3} \mathrm{Al}_{2} \mathrm{Si}_{3} \mathrm{O}_{12}$ from $350-1000 \mathrm{~K}$ and the entropy of pyrope. EOS, Trans. Am. Geophys. Union 58, 523.

PrandL W. (1971) Die magnetische struktur und die alomparameter des almandins $\mathrm{Al}_{2} \mathrm{Fe}_{3}\left(\mathrm{SiO}_{4}\right)_{3}$. Z. Kristallogr. 134, 333-343.

THompson J. B. and Hovis G. L. (1979) Entropy of mixing in sandine. Am. Mineral. 64, 57-65.

TOPOR N. D., Kieseleva I. A and Melchakova L. V. (1972) Measurement of the heat content of minerals by the method of high temperature microcalorimetry. Geokhimiya 335-343.

Ulbrich H. H. and WALDBaUM D. R. (1976) Structural and other contributions to the third-law entropies of silicates. Geochim. Cosmochim. Acta 40, 1-24.

Wfstrum E. F. Jr, Furukawa G. T. and McCullough J. T. (1968) Adiabatic low-temperature calorimetry. In Experimental Thermodynamics (eds. J. T. McCullough and D. W. Scott), pp. 133-214. Butterworths

Westrum E. F. JR, Essene E. J. and Perkins D. III (1979) Thermophysical properties of the garnet, grossularite $\left(\mathrm{Ca}_{3} \mathrm{Al}_{2} \mathrm{Si}_{3} \mathrm{O}_{12}\right)$. J. Chem. Thermodyn. 11, 57-66.

ZEMANN A. and ZEMANN A. (1961) Vereinerung der Kristallstruktur von synthetischen Pyrop, $\mathrm{Mg}_{3} \mathrm{Al}_{2}\left(\mathrm{SiO}_{4}\right)_{3}$ Acta Crystallogr. 14, 835-837. 